Martin D. Henry (ITQ, vol. 70/3, 2005, 195-214)

\title{
G. W. F. Hegel: A Secularized Theologian? ${ }^{1}$
}

This article pursues an idea underlying two previous contributions by the same author to the ITQ from the year 1998. It aims to examine the extent to which Hegel's thought is rooted in the Western theological tradition and draws its strength from it. At the same time, it argues that Hegel secularized that tradition, no doubt unintentionally, by reacting too recklessly against the notion of divine transcendence (that deist thinkers in the eighteenth century had endorsed), thus ultimately preparing the way for Karl Marx.

\section{Introduction}

Hegel (1770-1831) was the dominant philosophical figure of his own age and has remained a presence in the intellectual life of the modern world that cannot be ignored. His importance for contemporary thought lies in his having played such a defining role in its creation. He provided starting points for further intellectual enquiry, and most contemporary directions in philosophy, with the major exception of analytical philosophy, can be traced back to him. But his influence is much wider, for his vision of reality - his transformational or developmental understanding of history or his concept of experience, ${ }^{2}$ to take two examples - has affected the way the contemporary world now instinctively perceives itself.

1 This article, which takes up some material in Chapter 7 ('Hegel') of my On not understanding God (Dublin, 1997), continues an intended series that began in the ITQ seven years ago with the two articles: 'God in Postmodernity' (ITQ, 63 (1998) 3-21), and 'The Enlightenment and Romanticism from a Theological Perspective' (ITQ, 63 (1998) 250-62).

2 The Romantics' belief in the overriding significance of experience was put succinctly by Keats when he wrote that, 'Nothing ever becomes real till it is experienced-even a proverb is no proverb to you till your life has illustrated it' (The Oxford Dictionary of Quotations, 3rd ed. (Oxford, 1986), 294). The impact of such convictions on religion is hard to overestimate. If experience counts as the principal criterion of value, then a religion that can no longer be experienced as true or meaningful is in trouble. This is precisely Christianity's, and specifically, Catholicism's dilemma in the face of the widespread contemporary inability to find the Catholic church's rituals, rules and doctrine relevant to modern experience. 
Hegel is, however, a notoriously difficult philosopher to understand, but as a writer deeply imbued with the Romantic outlook of his age, he is by no means dry or pedantic. Roger Scruton has said of his philosophy: 'The spirit of late romanticism inhabits Hegel's system, and even his most abstruse utterances have a kind of melancholy poignancy. ${ }^{3}$ That he is, however, an extremely complex and perplexing thinker is beyond doubt, and he seems to have acknowledged the difficulty of his own thought when he remarked 'that only one man had understood him and he had understood him wrongly'. ${ }^{4}$ One listener, on hearing him converse, commented: 'I cannot tell whether he is brilliant or mad. He seems to be an unclear thinker.' ${ }^{5}$ The 'young Marx . . . who was an enthusiastic admirer of Hegel, speaks of his "grotesque craggy melody,", ${ }^{6}$ in a letter to his father, of November 1837. Not at all enthusiastic but rather unremittingly hostile was the reaction to Hegel of his most implacable nineteenth-century critic, Schopenhauer. In the work for which the latter is best known, The World as Will and Representation (1818), he wrote: 'Any time I opened the Phenomenology of Spirit, I always thought I was opening the windows of a madhouse. "7

But at least such judgements were made by Hegel's contemporaries or nearcontemporaries who may be assumed to have been still in tune with Hegel's own intellectual milieu. At a distance of nearly two centuries, it is more difficult for us to gain access to Hegel's world. Indeed, even in the 1870s, less than fifty years after Hegel's death, Wilhelm Windelband (1848-1915), in his History of Modern Philosophy, ${ }^{8}$ was claiming, as Richard

3 R. Scruton, A Short History of Modern Philosophy. From Descartes to Wittgenstein, 2nd ed. (London, 1995), 208. As an example of this 'melancholy poignancy' one could point to a passage in Hegel's lectures on the History of Philosophy, where he wrote: 'Philosophy begins with the decline of a real world; when it appears . . . , painting its grey in grey, the freshness of that world's youth and vitality has already disappeared . . .' (quoted in: K. Löwith, Von Hegel zu Nietzsche. Der revolutionäre Bruch im Denken des 19. Jahrhunderts (Hamburg, 1978), 53; cf. below n.83).

$4 \quad$ Mentioned by L. Kolakowski, Metaphysical Horror (Oxford, 1988), 101; (see also F. Overbeck, Christentum und Kultur, ed. C. A. Bernoulli, reprint (Darmstadt, 1963), 218f.). According to Heine (in Zur Geschichte der Religion und Philosophie in Deutschland: see Heines Werke in Fünf Bänden, vol. 5, selected and intro. by Helmut Holzhauer (Berlin/Weimar, 1976), 114), this complaint - characteristic of German philosophers - was made by Hegel on his deathbed.

5 'The description is by Ottilie von Goethe, quoted in Geoffrey Hawthorn: Hegel's Odyssey, London Review of Books, October, 1985' (Jonathan Glover, I: the Philosophy and Psychology of Personal Identity (Harmondsworth, 1991), 134, n.2).

${ }_{6} \quad$ Quoted in Hegel, The Encyclopaedia Logic, tr. with intro. and notes by T. F. Geraets, W. A. Suchting, and H. S. Harris (Indianapolis, 1991), xiii.

7 Cited in Steffen Dietzsch (ed.), Philosophen beschimpfen Philosophen. Die kategorische Impertinenz seit Kant (Leipzig, 1995), 57.

$8 \quad$ Geschichte der neueren Philosophie, 2 vols., 1878-80. 
Kroner notes, 'that the generation able to understand the Phenomenology [had] died out. ${ }^{9}$ We might despair of ever understanding Hegel. However, much attention has been lavished on his philosophy in the last half-century, and has undoubtedly helped to make it more accessible, or at least less forbidding, than it might otherwise be. But many enigmas and complexities remain, and will presumably always remain inseparable from the reading of Hegel.

Yet Hegel is awesome as well as difficult to read. The Phenomenology, especially, is an intoxicating mixture of passionate intensity and convoluted obscurity. As Kroner writes: 'The work claims to be rational, but it shows every evidence of having been written under inspiration. ${ }^{10}$ The source of 'Hegel's secret' may remain a matter of faith. But there can be little doubt that the fusion of passion and profound complexity pervading his writings accounts to some extent for the widely diverging reactions to his philosophy. J. N. Findlay’s comment that in reading Hegel one is 'at times only sure that he is saying something immeasurably profound and important, but not exactly what it is, ${ }^{11}$ seems fair and should hearten anyone trying to make sense of Hegel. To quote one of his own aphorisms: 'The condemnation which a great man lays upon the world, is to force it to explain him. ${ }^{12}$ This has certainly, in his own case, turned out to be a self-fulfilling prophecy.

Hegel's life coincided with the 'classical age' of modern German culture. This period (roughly 1750-1830) can itself be viewed as a re-enactment of the Renaissance on German soil. By the Renaissance I mean the attempt made by post-medieval European thinkers and artists to express a vision of reality and to develop a religious, political, legal, social and economic system out of their own resources, in debate with, but not in submission to, their historical traditions. It has often been argued that the backward and highly fragmented political state of Germany prevented its participating in any serious way in the Renaissance which had occurred in Italy, France, England and Spain from the fourteenth to the sixteenth centuries. Then in the seventeenth century Germany was devastated by the catastrophe of the Thirty Years War (1618-48), from which it took the German states over a century to recover. Thus, Germany was only in a position to enact or re-enact the Renaissance, so to speak, many centuries after it had been played out in other European lands. The significance of the Renaissance needs to be underlined, because it was the continuation of the intellectual and

$9 \quad$ Hegel, On Christianity. Early Theological Writings, tr. T. M. Knox, with an Intro., and Fragments tr. by R. Kroner (Gloucester, Mass., 1970), 43.

10 Early Theological Writings, 43.

11 From the 'Foreword' to G. W. F. Hegel, Phenomenology of Spirit, tr. A. V. Miller, with Analysis of the Text and Foreword by J. N. Findlay (Oxford, 1979), xiii.

12 Quoted by William Wallace (tr.) in his 'Prolegomena' to The Logic of Hegel (Oxford, 1874), xiii (this is a translation of the 'Lesser Logic’ from the Encyclopaedia). 
philosophical side of the Renaissance that finally brought forth the Enlightenment in western Europe and set the scene for the thought of Hegel and subsequently of Marx.

The 'classical age' of German culture, then, was the period during which many of the most famous German philosophers and theologians wrote their greatest works. On the philosophical side one could count Kant, Fichte, Schelling, Hegel and Schopenhauer, and on the theological, writers like Hamann and Schleiermacher. It was also the time when some of Germany's most celebrated literary figures - writers such as Lessing, Herder, Goethe, Schiller, Hölderlin and Kleist - were at the height of their powers, to say nothing of the galaxy of lesser, but still important, literary and philosophical lights of the same period. It is important to remember as well that many of these writers could fit into more than one of the categories mentioned. They were all interested in questions of general human concern, and cannot therefore be easily pigeon-holed into just one simple and exclusive category. Schleiermacher, for instance, was primarily a theologian, but he also wrote on philosophical and pedagogical issues, and, alongside his many other activities, was engaged for many years in translating Plato. Lessing, a playwright and critic, also wrote on theological and religious topics. Schiller was a poet and playwright, but also a professor of history and a theorist in aesthetics. Hegel himself, categorized normally as a philosopher, had a lifelong interest in religious and theological questions which profoundly marks his writings. Indeed some have interpreted his whole philosophical 'system' as a grandiose attempt to translate the meaning of Christianity into a modern idiom and thus rescue it from what for Hegel would have been an otherwise inevitable demise.

The great age of modern German culture was also perceived, or intuited, as being a time of transition, a point made with characteristically visionary power by Hegel, who raises the Enlightenment's sense of humanity's progress and perfectibility to an exciting, new level:

[I]t is not difficult to see that ours is a birth-time and a period of transition to a new era. Spirit has broken with the world it has hitherto inhabited and imagined, and is of a mind to submerge it in the past, and in the labour of its own transformation. Spirit is indeed never at rest but always engaged in moving forward. ${ }^{13}$

If one were to try to form a perhaps extremely general, but I think fundamentally valid, idea of his philosophy, one could begin by saying that Hegel is an optimist who sees meaning in life. But the meaning he sees is not simply a meaning that can be occasionally

13 From the 'Preface' to Hegel's Phenomenology of Spirit, tr. A. V. Miller, with analysis of the text and foreword by J. N. Findlay (Oxford, 1979), 6. 
glimpsed in and through the flux of things, though only fully existing in an eternally valid mode beyond the world of time and matter. Platonists of many hues have held such convictions. Rather, what is distinctive about Hegel is that he views the historical process itself as the means whereby truth or meaning is actually brought into being; it is created, not merely acknowledged or recognized.

What I have called the optimism of his 'system' might be more easily grasped, if contrasted with the equally problematic sense of the meaninglessness of historical existence that emerges from Macbeth's famous speech, delivered after the news of Lady Macbeth's death:

Tomorrow, and tomorrow, and tomorrow

Creeps in this petty pace from day to day,

To the last syllable of recorded time,

And all our yesterdays have lighted fools

The way to dusty death. Out, out, brief candle!

Life's but a walking shadow, a poor player

That struts and frets his hour upon the stage

And then is heard no more. It is a tale

Told by an idiot, full of sound and fury,

Signifying nothing. ${ }^{14}$

Or again, if one were to think of the sentiments expressed in Dostoevsky's Notes from Underground - 'one may say almost anything one likes about history, except that it is rational. The very word sticks in one's throat, ${ }^{15}$ - here too, as with Macbeth though with different accents, one finds a reaction to existence that is at the opposite end of the scale from Hegel. For Hegel, in contrast to Dostoevsky, history is rational, in the sense of being rationally comprehensible, and it is also, in contrast to 'Macbeth', substantial, not trivial, in its meaning. History is indeed, for Hegel, the story of absolute spirit's self-unfolding. 'Hegel assures us,' writes R. C. Solomon, 'that “to him who looks with a rational eye, history in turn presents its rational aspect.", 16

\section{Hegel's biography}

14 Macbeth, Act 5, Sc. V, ll. 19-28; cf. Peter Singer's remarks on Hegel in: B. Magee, The Great Philosophers (Oxford, 1987), 193.

15 Quoted by R. C. Solomon, Continental Philosophy since 1750 (Oxford, 1988), 63.

$16 \quad$ Ibid., 63. 
Hegel's family roots lie, partly, in Austria. In the sixteenth century a distant ancestor, Johannes Hegel, had moved as a Protestant from Kärnten (Carinthia) in Austria to Swabia, in the southwest corner of Germany, in order to escape religious persecution. ${ }^{17}$ And it was in Stuttgart, in the Duchy of Württemberg, in 1770, that the philosopher himself was born, five years before Schelling and eleven years after Schiller, two other eminent Württembergers. Swabia was an area marked by strong religious currents of pietism and mysticism, ${ }^{18}$ an influence that seems to have rubbed off on the young Hegel, or at least prepared him for his later study of the German mystical tradition, ${ }^{19}$ above all of Eckhart ${ }^{20}$ and Böhme. In 1788 he began his university studies as a candidate for the Lutheran ministry, entering the Tübinger Stift, the famous theology college where many important Swabians were educated. The astronomer Johannes Kepler (1571-1630) is a celebrated early example. And interestingly Kepler too, like Hegel, began his serious intellectual work under the influence of the sort of mystical, even pantheistic, Naturphilosophie ('philosophy of nature') that was prevalent in Swabia. In Tübingen Hegel soon abandoned any thought of becoming a Lutheran pastor, turning instead to philosophy, but without abandoning interest in the meaning and fate of Christianity in modern culture. Indeed his philosophy, like all German philosophy from Kant

See Rudolf Haym, Hegel und seine Zeit (Berlin, 1857), 16.

18 See Laurence Dickey, Hegel. Religion, Economics, and the Politics of Spirit, 1770 1807 (Cambridge, 1989), for a discussion of the pietist and eschatological (Joachimist) strands of thought in the Protestantism of Hegel's Württemberg; cf. also Edward Caird, Hegel (Edinburgh, 1883), 3-4.

Cf. David Walsh, After Ideology (San Francisco, 1990), 120: 'Hegel was an avid reader of the mystics, especially Eckhart and Boehme, whom he saw as the real originators of his own work. In the Lectures on the History of Philosophy he identified the two fountainheads of the modern world: Francis Bacon for the empirical inductive principle that is the basis of modern science, and Jacob Boehme as "the first German philosopher" to apprehend the necessity for a negative within the absolute identity of God.' See further Michael Inwood, A Hegel Dictionary (Oxford, 1992), 9: 'Paracelsus influenced the thought of Jakob Böhme (1575-1624), a shoemaker and mystic, whom Hegel regarded as the "first German philosopher", through whom "philosophy emerged in Germany with a character of its own".'

20 Eckhart is widely regarded as the fountainhead of modern German philosophical prose. Cf. Michael Inwood, A Hegel Dictionary, 8f.: '[T]he most important factor in the growth of philosophical German throughout the medieval priod (when mainstream philosophy was, as elsewhere, normally written in Latin) was German mysticism, which owed as much to Neo-platonism and to gnosticism as to Christianity. Its first major representative was the Dominican, Meister (Johann) Eckhart (c. 1260-1327).' 
onwards, was later to be dismissed by Nietzsche as merely a concealed, and thus dishonest, form of theology. ${ }^{21}$

While at Tübingen Hegel came into contact with Schelling, soon to make a name for himself as a philosopher, and Hölderlin, Germany's greatest poet of the classical period, who was to end, like Nietzsche, in madness. Both Schelling and Hölderlin shared Hegel's interest in religious and theological questions. After leaving Tübingen, Hegel worked for a number of years as a private tutor for families in Bern and Frankfurt. Eventually with Schelling's help he obtained a post as Privatdozent (unsalaried lecturer) at Jena, in the small state of Weimar. During his time at Jena he edited, along with Schelling, the Kritisches Journal der Philosophie, contributing many articles himself, and wrote his first major work: The Phenomenology of Spirit/Mind, which appeared in 1807, one of only four books that he actually published in his own lifetime. ${ }^{22}$ In the previous year, in which he had completed the manuscript, Hegel had been forced to flee from Jena because of the invasion of the city by Napoleon's troops.

After being forced out of Jena, Hegel moved to Nürnberg where for a brief period he edited a newspaper. This does not seem to have been entirely fortuitous, as he always had and retained to the end of his life a keen interest in contemporary events. One of his last writings, for example, was an article on 'The English Reform Bill'. And he is reputed to have said that 'the newspaper was modern man's version of morning prayers. ${ }^{23}$ From 1807 he was for eight years the principal of the local Gymnasium (secondary school). During his time in Nürnberg Hegel published the Science of Logic (Wissenschaft der Logik). In 1816 he was appointed professor in Heidelberg where he published the Enzyklopädie der philosophischen Wissenschaften im Grundrisse (Encyclopaedia of the Philosophical Sciences in Outline). In

${ }^{21}$ Nietzsche saw 'classical German philosophy', as it is sometimes called (cf. R. Scruton, 'Continental Philosophy from Fichte to Sartre', in: Anthony Kenny, ed., The Oxford Illustrated History of Western Philosophy (Oxford, 1997), 192), i.e. German idealist philosophy after Kant, as heavily indebted to (and hence, in his eyes, corrupted by) Protestant theology: 'Among Germans one will understand immediately when I say that philosophy has been corrupted by theologian blood. The Protestant pastor is the grandfather of German philosophy, Protestantism itself is its peccatum originale. . . . One has only to say the words "Tübinger Stift" to grasp what German philosophy is at bottom - a cunning theology. . . The Swabians are the best liars in Germany, they lie innocently. ...' (The Anti-Christ, tr. R. J. Hollingdale (Harmondsworth, 1990), 131).

22 The other three being: The Science of Logic (1812-16); The Encyclopaedia of the Philosophical Sciences (1817; rewritten ed. 1827; rev. ed. 1830; the Encyclopaedia includes the so-called Lesser Logic, to be distinguished from the earlier published, and fuller, Science of Logic); and The Philosophy of Right (1821).

23 Elie Kedourie, Hegel and Marx, ed. S. and H. Kedourie (Oxford, 1995), 2. 
1818 he succeeded Fichte as professor of philosophy in Berlin, and from then until his death in $1831^{24}$ he was at the height of his fame. In Berlin he produced his Naturrecht und Staatswissenschaft im Grundrisse and Grundlinien der Philosophie des Rechts, translated as the Philosophy of Right (1942) and as Elements of the Philosophy of Right (1991). From students' lecture notes the following works were published after his death: The Philosophy of Religion, The Philosophy of History, The History of Philosophy, and the Lectures on Aesthetics. The standard edition of Hegel's works ${ }^{25}$ runs to twenty-six volumes. There have also been more recent critical editions of some of his writings.

\section{Early Writings}

Hegel's early writings (from the 1790s) were not published until 1907. Although he does not appear to have considered them to be as important as his published works, they are nevertheless instructive for the light they cast on a critical phase of his intellectual development. Both his gradual outgrowing of the Enlightenment and his transformational grasp of the Christian doctrinal tradition are foreshadowed in these early works.

Hegel was by no means an out-and-out opponent of the Aufklärung. But in an important respect he found it shallow, because, although it had rightly insisted 'that happiness is the goal of both reason and life', it had 'failed because it interpreted happiness in secular terms only. ${ }^{26}$ Similar criticism of the philistine side of the Enlightenment can be found in many other nineteenth-century thinkers, who were otherwise antagonistic towards Hegel. Nietzsche, for instance, in Thus Spoke Zarathustra, paints a depressing picture of 'the last man' in his brave new world of regulated self-satisfaction ('we have invented happiness'). R. C. Solomon comments aptly: 'Here is the ideal of the Enlightenment in a revolting guise., 27

The shallowness of the Enlightenment Hegel himself expresses in the following poetical terms, where it is of interest to note his indebtedness to his own religious inheritance: 'The beautiful subjectivity of Protestantism is transformed by Enlightenment into an empirical subjectivity, and the poetry of its grief . . . into the prose of a satisfaction with this

24 The notion that Hegel died of cholera has been disputed; cf. A. Hügli/P. Lübcke (eds.), Philosophielexikon (Reinbek, 1997), 259, where it is suggested that 'Hegel probably died of a chronic stomach ailment and not, as the official diagnosis stated, of cholera'.

25 Ed. Hermann Glockner, Stuttgart, 1927-1940.

$26 \quad$ R. Kroner, in Early Theology Writings, 37.

$27 \quad$ Op. cit., 125. 
finite world. ${ }^{28}$ Yet despite misgivings about certain aspects of the Enlightenment, Hegel never lost the respect it inculcated for reason. To the end he always placed reason higher than feeling.

There is no doubt that Hegel was influenced, but not dominated, by the great current of thought and sensibility known as Romanticism, for which no aspect of life could ever be a matter of pure reason alone. Feeling was also involved. It was indeed, for many of the Romantics $^{29}$ though not for Hegel, deeper than reason. In his own writings, Hegel was forever mindful of the danger of appealing directly to feeling, which in his eyes did not go beyond the immediacy of experience. ${ }^{30}$ For this reason he could be scathing in his criticism of theologians like Schleiermacher who seemed to him to commit the cardinal sin of subjectivism, little different in his eyes from wilful self-assertion. ${ }^{31}$ He himself remained always reluctant to rest content with merely subjective convictions, seeking rather to transcend feeling and demonstrate the universal, intellectual defensibility of philosophical truth.

${ }^{28}$ Quoted by Kroner, op. cit., 38. The reference, as given by Kroner, is to Hegel, Werke, I, 10 (from an 1801 essay on 'Glauben und Wissen' [Faith and Knowledge]; = Theorie Werkausgabe, Werke, 2, ed. E. Moldenhauer and K. M. Michel, Frankfurt a/M, 1969, 294).

29 Cf. Faust's plausible defence of 'religious feeling' in the 'Marthens Garten' scene of Goethe (1749-1832), Faust Part 1, in answer to the so-called 'Gretchen-question' on the nature of Faust's religion (cf. M. Beddow, Goethe Faust 1 (London, 1986), 73): ' . . . Gefühl ist alles;/ Name ist Schall und Rauch,/ Umnebelnd Himmelsglut' (' . . . Feeling's surely all./ Names are but noise and smoke,/ Obscuring heavenly light', tr. P. Wayne (Harmondsworth, 1971), 153); or Chateaubriand's (1768-1848) statement of faith, which resolved the personal crisis brought on by the deaths of his mother and sister: 'Ma conviction est sortie du coeur. J'ai pleuré et j'ai cru' ('My conviction came from the heart. I wept and I believed' (cf. The Oxford Dictionary of the Christian Church, 3rd ed. (Oxford, 1997), 326).

30 There is surely, however, a case to be made for the advantage of having what might be called twin sources of authority in theology: feeling and reason, for example, as in the case of the Romantics, or revelation and reason, as in the case of the classical scholastic authors. Where only one source of truth is admitted, conclusions may be too readily and too unproblematically reached, but where two sources of truth are in play, the possible tension between the two can suspend conclusions that might be too hasty, and even allow for 'second thoughts' (metanoia?) on certain occasions.

31 To the very end of his life, however, Schleiermacher rejected this charge, claiming even on his deathbed: 'I must think the deepest, speculative thoughts, and they are to me completely at one with the most intimate religious sensations' (quoted by Karen Armstrong, A History of God (London, 1995), 403, from J. Macquarrie, Thinking about God (London, 1978), 162). That notwithstanding, the search for a rational, universally valid, systematic articulation of his deepest convictions is a more obvious and pressing concern of Hegel's writings than it is of Schleiermacher's. 
In one of his earliest works, The Spirit of Christianity and Its Fate, written in the 1790s, he broached the question of human 'estrangement' or 'alienation', a recurrent theme in his writings to which we shall return when dealing with his interpretation of the Fall. In the religion of the Old Testament, Hegel saw a vision of human alienation, alienation being for him the consciousness of separation between the self and the world. Abraham, in this early work, is a symbol for what Hegel takes to be the human predicament of alienation in the world. Alienation enters consciousness when the individual trespasses against a law, and because of his bad action experiences a rupture within his own life. Yet this very problem prompts the search for an appropriate solution: 'When the trespasser feels the disruption of his own life (suffers punishment) or knows himself (in his bad conscience) as disrupted, then the working of his fate commences, and this feeling of a life disrupted must become a longing for what has been lost. The deficiency is recognized as a part of himself, as what was to have been in him and is not. ${ }^{32}$ The search for the solution to this existential problem was to engross Hegel in his mature philosophy.

Between his earliest writings on the meaning of Christianity and his later, betterknown works, Hegel clearly found reason to abandon, not the Enlightenment's commitment to rational thought as such, but the unimaginative side of that rationalism (for instance, its failure to see the profound human significance of the story of the Fall). It was this unimaginative side of the Enlightenment that blinded it to the deeper meaning of existence that Hegel was eventually to reconstruct for himself out of the Christian doctrinal tradition.

He came to believe that it was implausible to conclude, with the Aufklärung, that historical Christianity represented only stupid superstition. Rather its theology could be shown to contain the most profound truth about the human condition, but a truth that now had to be expressed in a different idiom. Hegel's new project then 'would derive that now discarded theology from what we now know as a need of human nature and would thus exhibit its naturalness and inevitability'. ${ }^{33}$ To attempt such a project would of course mean assuming that 'the convictions of many centuries, regarded as sacrosanct, true, and obligatory by the millions who lived and died by them in those centuries, were not, at least on their subjective side, downright folly (barer Unsinn) or plain immorality. ${ }^{34}$ But what historical Christianity had hitherto, i.e. up until modern times, expressed in a symbolic or

32 Early Theological Writings, $230 \mathrm{f}$.

33 Early Theological Writings, 172 (from a revised form, written in 1800, of early sections of The Positivity of the Christian Religion).

$34 \quad$ Ibid.; cf. J. C. Livingston, Modern Christian Thought from the Enlightenment to Vatican II (New York, 1971), 149f. 
representational (Vorstellung) mode, had now to be transcended (aufgehoben), or translated into a conceptual form (Begriff), a task which Hegel was convinced could and should be carried through 'without remainder'.

\section{Later Writings}

In 1807 Hegel's first major work, The Phenomenology of Spirit (Die Phänomenologie des Geistes), was published. Built around three key-terms, Spirit/Dialectic/Concept, ${ }^{35}$ the Phenomenology presents a first, comprehensive account of the Hegelian 'system'. If one dared to try to sum it up the meaning of this work in one sentence, one could say that it tells the story of the self-realization or self-becoming of Absolute Spirit as a result of its journey through the dramatic history of human consciousness, 'without which it would be lifeless and alone. ${ }^{36}$ In German, Geist means both 'spirit' (the translation used here) and 'mind'. That is to say, it has at once an intellectual and a more 'religious' or 'spiritual' sense (English 'ghost', cognate with Geist, is of little help here), which in English neither 'mind' nor 'spirit' alone can capture. In trying to understand Hegel's excruciatingly difficult thought and style, it might be useful, provisionally at any rate, to think of 'Spirit' as being what he means by 'God', provided we remember that Hegel's 'God' is not the transcendent, creator God of traditional Christianity.

While there is clearly intense, passionate feeling expressed in the Phenomenology, so that it reads, as already mentioned, like a book written under some kind of inspiration, Hegel strove nonetheless to impose stringent conceptual form (as he understood it) on his quasivisionary material, and was dismissive of those (like the theologian Schleiermacher) who either failed to see, or who contested the necessity of, this step. He distanced himself from such writers, when he described their views in the 'Preface' to the Phenomenology, with evident disapproval: 'For the Absolute is not supposed to be comprehended, it is to be felt and intuited; not the Concept [Begriff] of the Absolute, but the feeling and intuition [Gefühl und Anschauung] of it, must govern what is said, and must be expressed by it. ${ }^{37}$ On the contrary,

35 For consistency 'concept' will always be used to translate Begriff, even when using translations or references which prefer 'notion'.

36 Phenomenology of Spirit, 493 (changing 'he' to 'it').

37 Phenomenology of Spirit, 4; cf. Findlay's comments, ibid., 495. Hegel returned to the attack in the 'Introduction' to his Encyclopaedia (1817), where he wrote sarcastically: '[The] comfortable view of what constitutes a philosopher has recently received a fresh corroboration from the theory of immediate or intuitive knowledge [die Lehre vom unmittelbaren Wissen, Wissen durch Anschauen]' (tr. W. Wallace). 
for Hegel feeling is only the beginning of the knowledge of God; the immediacy and particularity of feeling has to be transcended (aufgehoben) and its content conceptualized and hence universalized by the mind's rational effort. For Hegel, this was not a luxury, but a necessity. For the age ushered in by Christianity, he believed, was the period in which 'the final purpose of the world has at last passed into actuality in a universally valid and conscious way. ${ }^{38}$ It was up to Christian thinkers, therefore, to spell out philosophically the full meaning of the definitive disclosure of the meaning of the world that, for Hegel, Christianity represented.

In setting about this task himself, Hegel retains many formal aspects of the 'Christian story', but with a radically new content. This can be seen particularly clearly in his treatment of the Fall. Hegel's interpretation of this ancient Christian doctrine was anticipated, as we have seen, in his early writings, by the notion of alienation, but it was given much fuller development in his later works. ${ }^{39}$ The Fall is pivotal in Hegel's thought, as it gives him the specific starting point he needs for his intellectual journey towards God, or 'absolute knowledge'. The Fall for Hegel is in fact nothing less than the actual emergence of selfconsciousness which enables the individual to distinguish between self and the rest of reality. In The Philosophy of History, he writes:

This is a deep truth, that evil lies in consciousness: for the brutes are neither evil nor good; the merely Natural Man quite as little. Consciousness occasions the separation of the Ego, in its boundless freedom as arbitrary choice, from the pure essence of the Will-i.e. from the Good. Knowledge, as the disannulling of the unity of mere Nature, is the "Fall," which is no casual conception, but the eternal history of Spirit. For the state of innocence, the paradisaical condition, is that of the brute. Paradise is a park, where only brutes, not men, can remain. For the brute is one with God only implicitly [not consciously]. Only Man's Spirit (that is) has a self-cognizant existence. This existence for self, this consciousness, is at the same time separation from the Universal and Divine Spirit. If I hold to my abstract Freedom, in contraposition to the Good, I adopt the standpoint of Evil. The Fall is therefore the eternal Mythus of Man-in fact, the very transition by which he becomes man. Persistence in this standpoint is, however, Evil, and the feeling of pain at such a condition, and of longing to transcend it, we find in David, when he says: 'Lord, create for me a pure heart, a new steadfast Spirit.' 40

\footnotetext{
$38 \quad$ Quoted by Livingston, op. cit., 150.

39 Cf. Livingston, op. cit., 169, n.23.

40 The Philosophy of History, tr. J. Sibree (New York, 1956), $321 \mathrm{f}$.
} 
Man’s 'Original Sin', that which makes him human, is therefore knowledge itself. ${ }^{41}$ Once the disjunction between the individual and God is consciously known, however, the individual can set out on the path leading to reconciliation with God. Without the Fall, which leads to the separation ${ }^{42}$ between man and reality, however, the journey to God would never get started. In this sense, as Hegel puts it in the so-called 'Lesser Logic': 'The hand that inflicts the wound is also the hand which heals it. ${ }^{43}$ The Fall is thus also in Hegel, as in the mainline Christian tradition, a felix culpa [happy fault], leading to the acquisition of a greater good than what was lost, although it should be noted that for traditional Christianity the Fall is tied to the exercise of human freedom, whereas for Hegel it is a necessary evil. But for Hegel too - and here there is at least a formal similarity with Christian teaching - the projected reconciliation will not simply be a return to the pre-conscious unity with God which is what the brute beasts enjoy, but which can no longer satisfy man; rather it will be a consciously achieved, conceptually articulated and hence universalizable reconciliation. ${ }^{44}$

The reconciliation with God is charted in the various stages of the Phenomenology, in the epic adventure by which God or Absolute Spirit, through its embodiment in the history of human consciousness, achieves the fullness of its own reality. But the historical human condition whose truth is mythically contained in the story of the Fall is one of wretchedness, because of the many dimensions of man's alienation from God. The texture of human alienation Hegel anatomizes in a famous section of the Phenomenology ${ }^{45}$ where he discusses the ‘unhappy consciousness’ (das unglückliche Bewußtsein):

41 Cf. The Logic of Hegel (from the Encyclopaedia), tr. W. Wallace, 47: '[T] of spirit is enough to show that man is evil by nature, and that it is an error to imagine that he could ever be otherwise . . . Nature is for man only the starting-point which he must transform into something better.'

42 'The beasts never get so far as this separation, and they feel no shame,' as Hegel puts it in the Encyclopaedia (The Logic of Hegel, 46).

$43 \quad$ The Logic of Hegel, 46.

44 Nietzsche, not surprisingly, takes a different tack, and resists what he calls this 'Pride in the spirit' in a passage of Daybreak, where he writes: 'During the great prehistoric age of mankind, spirit was presumed to exist everywhere and was not held in honour as a privilege of man. Because, on the contrary, the spiritual [das Geistige] (together with all drives, wickedness, inclinations) had been rendered common property, and thus common, one was not ashamed to have descended from animals or trees (the noble races thought themselves honoured by such fables), and saw in the spirit that which unites us with nature, not that which sunders us from it' (Daybreak, tr. R. J. Hollingdale (Cambridge, 1983), 23). Characteristically, Nietzsche sees both positions as resting on prejudices...

45 Phenomenology of Spirit, 119-138. 
The pages on the unhappy consciousness introduce us to some of the fundamental ideas of Hegel's philosophy of religion. We recognize the themes of Hegel's writings on religion of the 1790s, in particular the theme of separation, where man projects his lost unity into a transcendent spirit to whom he subjects himself absolutely, as in the religion of Abraham. ${ }^{46}$

In the unhappy consciousness, then, the self is torn between its embeddedness in the mutable world and its longing for union with a projected, immutable transcendent reality where it can be 'at home', since in its depths it feels itself to be an 'immutable self-identical subject of thought'. ${ }^{47}$ We can see, Taylor notes, ${ }^{48}$ in Hegel's reflections on the unhappy consciousness 'the origin of the Feuerbachian and Marxian conception of religious consciousness as alienated'. For Hegel, however, God will be seen as not apart from or separated from the world ultimately, and hence the possibility of overcoming alienation can be actualized. But a God who remained apart from the world would always leave the human spirit alienated.

\section{Spirit/Dialectic/Concept}

We can now look more closely at the three key-terms ${ }^{49}$ of the Phenomenology: spirit/dialectic/concept beginning with Spirit (Geist). Spirit is, for Hegel, the ultimate reality, 'the substance of things, ${ }^{50}$ Matter too is real, it is not an illusion; but ultimately what matter itself really is, is spirit. For spirit projects itself necessarily into the alien element of matter, but is destined to return finally to itself, having enriched itself with the experience gained during its 'exile' in matter. In a double movement of exit and return (exitus and redditus), reminiscent of Neoplatonism, ${ }^{51}$ spirit moves into matter, and man - embodied spirit emerges from matter as self-consciousness. History, building upon nature, is the necessary process by which the Absolute (spirit) becomes itself or achieves its complete self-realization. It is indeed a doubly necessary process in the sense that not only is it the sole way in which

$46 \quad$ Taylor, Hegel (Cambridge, 1977), 160.

47 Ibid.

48 Hegel, 160, n.1. Taylor adds: 'Not that Feuerbach and Marx had the same notion of religion as Hegel, of course. These successors “anthropologized” Hegel's Spirit.' Cf. Macquarrie, In Search of Deity (London, 1984), 130. The above discussion of these terms follows Macquarrie closely.

Op. cit., 209.

Cf. Macquarrie, op. cit., 130. The enthusiasm of the German Romantics of the 1790s for Plotinus has been commented on by students of the period: cf. Arthur O. Lovejoy, The Great Chain of Being (Cambridge, Mass., 1974), 298, 371, n.18. 
spirit can become, or realize, itself, but it is also a process which, according to Hegel's system, spirit has no choice but to undergo. There is, seemingly, no going behind this process, as it were, to ask: 'Why?' To understand it, appears to be, for Hegel, to know why it has to be as it is and cannot be otherwise. Real difference, real otherness, as between spirit and matter, or between absolute spirit and man, is thus, finally, a fiction; both are in the last analysis identical. All otherness is absorbed by the ultimate sameness or 'monism' of spirit.

Hegel defines the meaning of spirit in the 'Preface' to the Phenomenology in the following difficult terms:

That the True is actual only as system, or that Substance is essentially Subject, is expressed in the representation of the Absolute as Spirit-the most sublime Concept and the one which belongs to the modern age and its religion. The spiritual alone is the actual; it is essence, or that which has being in itself; it is that which relates itself to itself and is determinate, it is other-being and being-for-itself [das Anderssein und Fürsichsein], and in this determinateness, or in its self-externality, abides within itself; in other words, it is in and for itself. ${ }^{52}$

The essence of spirit is dynamic form, the creativity which constructs an ordered universe out of matter. Spirit goes out from itself, yet continues to be itself in a mutual relationship of itself (as 'pure' spirit, so to speak) to itself (as materialized or embodied or externalized spirit). This may be Hegel's way of developing an idea of Meister Eckhart's, whom he quotes approvingly in the Lectures on the Philosophy of Religion: 'The eye with which God sees me, is the eye with which I see him; my eye and his eye are one. . . . If God were not, I would not be; if I were not, neither would he be. ${ }^{53}$ In Macquarrie's words, 'As subject', spirit 'knows itself as reflected in the object, while the object in turn knows spirit as the original subject. ${ }^{54}$ In short, spirit as subject and spirit as object are somehow the same, even though in its alienated state nature is not (yet) cognizant of its true nature, so to speak, though in man it is destined to be so eventually, thanks to the labour of the 'concept' (Begriff) which seems to be Geist in action in human self-consciousness. Nature ${ }^{55}$ is 'self-alienated spirit', but 'in nature, the unity of the

\section{$52 \quad$ Phenomenology, 14.}

53 Vorlesungen über die Philosophie der Religion, Theorie Werkausgabe,Werke 16, (Frankfurt a/M, 1969), 209; (cf. B. M. G. Reardon, Religion in the Age of Romanticism, Cambridge, 1985, 65).

${ }_{54}$ Macquarrie, op. cit., 130.

55 Nature is the second of the 'three main phases in the construction of the life of the Absolute', the 'logical Idea . . . and Spirit' being the other two (F. Copleston, A History of Philosophy, Vol. 7, Pt. 1 (New York, 1965), 215). A logical Idea, for Hegel, 'is not a subjective or mental entity ... . [it] is the full realization or actualization of a concept 
Concept conceals itself'. ${ }^{56}$ In the process whereby spirit goes out from itself into the world, 'spirit and matter, God and world, are not separate but correlative': 57 'Now nature is, however, far from being so fixed and complete, as to subsist even without spirit: in spirit it first attains its aim and its truth. And similarly, spirit on its part is not merely an abstract world beyond nature and nothing more: it is really, and with full proof, seen to be spirit, only when it contains nature as absorbed [aufgehoben] in itself., 58

Thought ('mind', 'spirit', 'consciousness', 'God') and material reality are therefore, if the interpretation suggested here is correct, ${ }^{59}$ ultimately identical for Hegel (hence, the

(which, too, is not a mental entity): an idea is thus true or the truth. An idea is not transcendent and separate from particulars: it is fully realized in certain types of particular' (Inwood, A Hegel Dictionary, 124). The Absolute (or 'God') comes, seemingly then, to full self-realization through actualizing itself as Ideas in the alien element of matter (Nature), where both Ideas and Nature are expressions of Absolute Spirit, the former as Concepts, the latter as self-alienated Spirit. For Hegel 'the world is a process, each phase of which conditions, but is sublated by, the next phase. Of its main phases, for example, the logical idea conditions nature, which in turn conditions spirit, which then conditions the logical idea; the world is a circle of successively sublated conditions' (Inwood, ibid.; 'sublated' is the usual translation of the key-Hegelian term aufgehoben (from aufheben), meaning both 'cancelled' or 'annulled' and preserved (literally: 'lifted up'), thus 'transcended but not entirely discarded', as it were. The Encyclopaedia, Pt. II, §247, quoted by Taylor, op. cit., 353.

Macquarrie, op. cit., 130.

The Logic of Hegel, 154f. (amended).

It should be pointed out that some commentators give a much more anti-metaphysical reading of spirit or Geist than has been proposed here. Thus the distinguished Hegel scholar, J. N. Findlay, sees Geist as appearing only relatively late in the historical day, and in no sense the driving power behind nature and history. Rather for him, Geist represents a way of looking at the reality of the world, at a specific stage of its development: 'Hegel's . . . abolute idealism . . . is not the belief that all things exist only in and for a consciousness, but that all things must be seen either as necessary conditions of, or as stages towards, self-conscious rationality, towards the conscious rational use of universals, or as Hegel calls it, Geist or Spirit. What does Hegel mean by saying that Geist is the truth of everything, and is such an affirmation in any way valid or acceptable? ... [T] his assertion is not to be metaphysically understood: it does not go beyond the facts of human experience, its sense lies in the daylight of our conscious rational life. Geist is in fact exemplified in the three forms of Art, Religion and Philosophy: it is there and nowhere else that Hegel's Absolute is to be found. And that Geist is the truth of everything does not mean that Geist engineered the world, or was causally responsible for it: Geist makes its appearance at a comparatively late stage in the world's history, its supreme stage, philosophy, is even said to arrive in the world when the shades of night are falling. Clearly the sense in which Geist is the truth of everything in the world is a perspectival sense: it is an Ansicht, a peculiar view of the facts of experience-Hegel sometimes characterizes is as the removal of an illusionnot something which underlies the universe or is causally responsible for it' ( $\mathrm{J}$. N. 
'identity of identity and non-identity ${ }^{60}$ ): material reality is the expression of mind in exile (its being-other), of spirit outside itself. Hegel overcomes, then, the traditional subject/object dichotomy by what often appears as a ruse, asserting the final identity of mind and matter. Spirit is the creative energy shaping the world, or - looked at from a slightly different angle spirit is that power which comes and must come to knowledge of itself, and can only come to knowledge of itself, in and through the necessary process of world-history. The final justification of the world is that it enables 'absolute spirit' to achieve its own absolute selfknowledge.

We come now to dialectic (Dialektik). In trying to understand what Hegel means by dialectic, one common misconception should be avoided. As Walter Kaufmann points out: '[I]t is a commonplace' to suppose 'mistakenly, that all of Hegel is reducible to the three-step Thesis, Antithesis, and Synthesis. As a matter of fact, he does not speak of theses, antitheses, and syntheses at all, although his immediate predecessors, Fichte and Schelling, did; and neither his analyses in the Logic nor his dialectic in general can be reduced to any such threestep. ${ }^{61}$ In Kaufmann's interpretation, Hegel's vision of history is that 'different outlooks

Findlay, 'The Contemporary Relevance of Hegel', in A. MacIntyre, ed., Hegel: A Collection of Critical Essays (New York, 1972), 16; cf. John Cottingham, Rationalism (London, 1984), 94). Cottingham also argues that Hegel is not concerned with eternal, immutable verities, but with how the world in fact works, the process by which it lives and moves. Seen from this perspective, then, Geist is 'an ultimate stage of development towards which history moves. Geist, as Hegel insists, . . . is not an Aristotelian primemover or a Cartesian eternal perfect being. Rather it emerges out of the progressive struggle of humanity to realize itself and understand the world' (Cottingham, ibid.).

Quoted in Taylor, Hegel, 48.

See J. O. Urmson and J. Rée (eds.), The Concise Encyclopedia of Western Philosophy and Philosophers (London/New York, 1991), 127; cf. Inwood, A Hegel Dictionary, 12: "To Fichte we owe . . . the triad "thesis-antithesis-synthesis", often wrongly attributed to Hegel'; see, further, ibid., 81: 'Fichte's three-step procedure of a thesis (the I posits itself), an antithesis (the I posits a non-I), and a synthesis (the I posits in the I a divisible non-I in opposition to the divisible I) also influenced Hegel's dialectic. (But Hegel uses the terms "thesis", “antithesis”, "synthesis” only in his account of Kant.)' See, finally, ibid., 297f.: "Hegel does not apply the terms "thesis", "antithesis" and "synthesis" to his own triads, and uses them together only in his account of Kant's triads. But he owes much to Fichte's triadic procedure, and often describes his own procedure as one of overcoming oppositions by dialectical and speculative reason.'

The point is reinforced by Sidney Hook: 'The least significant aspect of the dialectical method is its division into triadic phases. Although there is an historical tradition behind the idealistic dialectic which the carries the "triad" at least as far back as Proclus, it is not logically essential to the method. . . It is not so much the number of phases a situation has which makes it dialectical but a specific relation of opposition between those phases which generates a succession of other phases. The necessary condition, then, of a dialectical situation is at least two phases, distinct but not separate. The 
correspond to different states of mind, different stages in the development of the spirit', ${ }^{62}$ so that one age improves on, and develops from, its predecessor; none is right or wrong, but all are on the way towards an ever fuller grasp of the truth. The assumption of such a linear progress, which inspires the Phenomenology, remains unproved and is surely unprovable. But what moves the whole process along - its inner soul, so to speak - is what Hegel seems to mean by 'dialectic'.

The actual term 'dialectic' is derived from the ancient Greek word for conversation or debate, and refers basically to the argumentative process by which truth is sought on any topic. It can mean, as in the 'Socratic method', the process of bringing truth to light through

sufficient condition of a dialectical situation is given when those two phases present a relation of opposition and interaction such that the result (1) exhibits something qualitatively new, (2) preserves some of the structural elements of the interacting phases, and (3) eliminates others’ (S. Hook, From Hegel to Marx (London, 1936), 61).

For a longer discussion of this whole question see the article by Gustav E. Mueller, 'The Hegel Legend of "Thesis-Antithesis-Synthesis"', in Jon Stewart (ed.), The Hegel Myths and Legends (Evanston, Illinois, 1996), 301-305; see also Stewart's own 'Introduction', ibid., 1, 15. Mueller argues that this particular legend was in fact 'spread by Karl Marx, whose interpretation of Hegel is distorted. It is Marxism superimposed on Hegel. Thesis, antithesis, synthesis, Marx says in Das Elend der Philosophie ['The Misery of Philosophy'], is Hegel's purely logical formula for the movement of pure reason, and the whole system is engendered by this dialectical movement of thesis, antithesis, synthesis of all categories. This pure reason, he continues, is Hegel's own reason, and history becomes the history of his own philosophy, whereas in reality, thesis, antithesis, synthesis are the categories of economic movements' (op. cit., 304: summary of Karl Marx, Das Elend der Philosophie (Berlin, 1957), chap. 2, par. 1). Mueller, with the bit now firmly between his teeth, continues: 'The few passages in Marx's writings that resemble philosophy are not his own. He practices the communistic habit of expropriation without compensation. Knowing this in general, I was convinced that there must be a source for this "thesis, antithesis, synthesis," and I finally discovered it' (ibid.). Mueller claims to find this source in a popular general work on post-Kantian philosophy that first appeared in 1837, which contains the following passage: " "This is the first trilogy: the unity of Being, Nothing and Becoming . . . we have in this first methodical thesis, antithesis, and synthesis . . . an example of or schema for all that follows" [Heinrich Moritz Chalybäus, Historische Entwicklung der speculativen Philosophie von Kant bis Hegel, $\mathrm{Zu}$ näherer Verständigung des wissenschaftlichen Publikums mit der neuesten Schule, 3rd ed., 1843, 354]. This was for Chalybäus a brilliant hunch which he had not used previously and did not pursue afterwards in any way at all. But Karl Marx was at that time [1837] a student at the University of Berlin and a member of the Hegel Club where the famous book was discussed. He took the hunch and spread it into a deadly, abstract machinery. Other leftHegelians, such as Arnold Ruge, Ludwig Feuerbach, and Max Stirner use "thesis, antithesis, synthesis” just as little as Hegel. . . . Brutal simplifications are Marxistic specialities' (ibid.).

Ibid. 
persistent questioning, sometimes revealing inconsistencies or contradictions in an opponent's beliefs or assertions. Plato, in some of his dialogues, uses the term to mean 'the total process of enlightenment, ${ }^{63}$ leading to the attainment of knowledge of the supreme good. For Aristotle, who deals with the subject in Topics, Books 7 and 8, dialectic is a respectable method of arguing for the validity of an opinion, but it 'is inferior to logic, which teaches how to establish proofs. ${ }^{, 64}$ Dialectic, for Kant, "is the "logic of illusion", or the misuse of logic to deliver the appearance of solid belief. ${ }^{65}$ Serious philosophy, therefore, must show the limits of reason's reach. In Hegel, dialectic refers both to a process of reasoning and to the process of history itself, history being, for Hegel, 'the march of reason in the world' ${ }^{66}$ In other words, he believed 'that thought is not distinct from things, but is embedded in them and responsible for their nature and development. ${ }^{67}$ The claim that the dialectical process of reasoning and the dialectical process of history itself are essentially the same has been, not surprisingly, baffling for many readers, although it should perhaps be added that 'the idea that processes in the world unfold in a way that mirrors the processes of reason is as old as Heraclitus. ${ }^{68}$

In Hegel, then, the process 'whereby spirit unfolds and realizes itself in material nature and in history is a dialectical one, characterized by the clash of opposites which are then reconciled in a higher synthesis', ${ }^{69}$ or at a higher level. Historical movements provoke antagonism or criticism, and the result of the conflict is change which brings about a new state of affairs, incorporating at a higher level (Aufhebung) what was 'true' about the previous historical stage. The new stage in turn eventually provokes dissatisfaction, and so history develops, changes and advances.

But what the whole dialectical process amounts to, for Hegel, is - seemingly - a grandiose, cosmic reconciling that occurs, as it were, within the life of self-differentiating, absolute spirit, whereby the dialectical movement of history coincides with the dialectical 'laws' regulating thought. Seen in even tighter terms, following Van Harvey: 'The Infinite

63 Simon Blackburn (ed.), Oxford Dictionary of Philosophy (Oxford, 1996), 104.

64 Thomas Mautner (ed.), The Penguin Dictionary of Philosophy (London, 1997), 141.

65 Blackburn (ed.), op. cit., 104.

66 Quoted by Scruton, A Short History of Modern Philosophy, 175.

67 Inwood, A Hegel Dictionary, 16.

68 Blackburn (ed.), op. cit., 104. It was Heraclitus (c.540-c.475 BC) who first popularized the notion of logos as the fundamental principle behind all reality and, specifically, as the principle of human intelligence. This need not necessarily mean that any interpretation of the cosmos is simply a projection of the workings of the human mind on to the universe. But it does seem to imply that both the universe (external reality) and the human mind (internal reality) belong to one and the same system of things, which thought alone cannot transcend. 
perpetually pours out (objectifies) its life in the finite (creation), struggles with the resulting externality (self-alienation) until finally overcoming it in self-knowledge (freedom). ${ }^{, 70}$ In the famous closing section of the Phenomenology, Hegel powerfully and memorably visualizes the self-realization of the truth of absolute spirit emerging out of history. History has to happen and die so that its truth can be 're-membered' conceptually, and thus preserved, in a 'speculative' form of Resurrection. The whole process of history is thus the story of the evolution of spirit or God. God had to 'alienate' ('incarnate'?) himself in time, space and matter, in order eventually to become himself fully as 'Absolute Spirit': 'Only from the chalice of this realm of spirits/ foams forth for Him his own infinitude. 71

We come finally to the term 'concept' (Begriff). This expression is best considered in contrast with Hegel's use of another important term, 'representation' or 'image' (Vorstellung). For Hegel the concept 'goes beyond simple representation and is a thinking of something in depth or in several dimensions. ${ }^{72}$ The concept, therefore, 'grasps something not just as it immediately presents itself, but as it has come to be in the course of its dialectical development." 73

This is of central importance for Hegel, since he sees truth as being conveyed representationally or symbolically in the 'religious' stage of human development, whereas the movement beyond the religious stage will be the philosophical conceptualization of this absolute truth offered by his own system of thought. ${ }^{74}$ The religious perception of truth occurs through feeling, and it is, for Hegel, the beginning of knowledge: '[T]he immediate consciousness of God goes no further than to tell us that he is: to tell us what he is would be an act of cognition, involving mediation. ${ }^{75}$ Religion, therefore, 'remains in the realm of the idea (Vorstellung), in the sense of "representation" or "image”, an immediate and therefore partial view of something in one of its moments. Philosophy pushes on to the concept (Begriff), the sum of the moments in their necessary unity. For instance, religion represents God as Father, Son and Holy Spirit, philosophy goes beyond this to grasp the dialectical unfolding of spirit. ${ }^{\text {, }}$

\footnotetext{
70 See Van A. Harvey, 'Ludwig Feuerbach and Karl Marx', in Ninian Smart et al. (eds), Nineteenth-Century Religious Thought in the West (Cambridge, 1985), vol. 1, 293. Phenomenology of Spirit, 493.

Macquarrie, op. cit., 131.

Ibid.

Cf. Livingston, op. cit., 150: 'Historical Christianity had grasped the truth in representational form, but philosophy grasps this same truth in its rational necessity.'

75 Logic, 136 (quoted in Macquarrie, ibid.).

76 Macquarrie, ibid.
} 
The 'absolute Concept' would, then, for Hegel be the whole of reality, thinking and knowing itself in all its moments: ${ }^{77}$ '[S]imple infinity or the absolute Concept is the simple essence of life, the soul of the world, the universal blood, whose omnipresence is neither disturbed nor interrupted by any difference, but rather is itself every difference, as also their supersession [Aufgehobensein]; it pulsates within itself but does not move, inwardly vibrates, yet is at rest. It is self-identical, for the differences are tautological; they are differences that are none. $^{78}$

The progressive self-knowledge of absolute spirit is also the story of freedom. In knowing itself progressively in history, spirit is also continually freeing itself from what eventually come to be understood as inadequate embodiments of itself and moving on to ever more adequate ones, until finally absolute spirit's full self-knowledge will coincide with its full freedom. One can see why Hegel's philosophy has been perceived as being politically Janus-faced, in that it could be seen as an endorsement of any existing state of affairs, however bad, (the real, i.e. what is actually now existing, is the rational and so should be maintained), or as a call to radical revolution (only what is rational should be regarded as real and so, if any given state of affairs is deemed to harbour irrationality and inconsistency within its bosom, it should be overthrown). ${ }^{79}$

The irremovable ambiguity at the heart of Hegel's system would seem to be bound up with his debatable notion of rationality, as with his attempt to accommodate in his thought both freedom and necessity. Some have argued in his defence that, for Hegel, freedom is not simply the arbitrary liberty to do what one likes, which could clearly lead to tyranny, but rather the possibility 'of living self-consciously and in a fully rationally organized community or state'. ${ }^{80}$ Others, like Hegel's inflexible censor Karl Popper, ${ }^{81}$ have seen in his philosophy a recipe for totalitarianism, since it seems to endorse the notion of historical necessity, from which an equivocal notion of freedom offers little real hope of escape. Such strictures, however, may seem somewhat harsh, if one accepts that for Hegel the rational state must have

\footnotetext{
77 This is reminiscent of Aristotle's idea of God as 'a thought which thinks itself', except that for Hegel 'God' becomes the process of life itself.

Phenomenology, 100 (amended).

79 It might be useful to point out at this juncture that the statement 'all that is real is rational', which Engels quoted from Hegel from memory in 1888 (see the article by M. W. Jackson, 'Hegel: The Real and the Rational', in: J. Stewart, ed., The Hegel Myths and Legends, 20), is not an accurate quotation, but it did give rise to the widespread and seemingly incorrigible - although, for many commentators, unfair - impression, that Hegel advocated 'a quiescent authoritarian politics or worse' (ibid.).

$80 \quad$ Blackburn (ed.), op. cit., 168.

81 The Open Society and Its Enemies (London, 1945), vol. 2.
} 
'the consent of the rational conscience of its members. ${ }^{82}$ But then, who decides what is 'rational'? The ambiguities remain.

\section{Continuing Significance of Hegel}

While it is true that the success of Hegel's system as a complete explanation of existence was short-lived, many aspects of his thought have continued to be of incalculable importance in the modern world. Truth is now conceived by many as no longer timeless, complete and immutable and existing apart from us, but rather it is conceived as continually developing and, in some sense, being fashioned by the historical process itself. The almost axiomatic acceptance of this point of view is implicit in the sensitivity now obligatorily shown to the historical background and context of any contemporary political problem by serious commentators.

For Hegel, and even more resolutely for Marx too, truth does not exist objectively in a realm transcending ours and waiting to be discovered by metaphysical enquiry, but truth inheres rather in the historical process itself and has to be actually created or made by human beings before it can be intellectually grasped. This was poetically stated by Hegel in the 'Preface' to the Philosophy of Right:

When philosophy paints its grey in grey, a shape of life has grown old, and it cannot be rejuvenated, but only recognized, by the grey in grey of philosophy; the owl of Minerva begins its flight only with the onset of dusk. ${ }^{83}$

One should not underestimate the shift which the Hegelian, historical - or 'historicist ${ }^{84}$ one is tempted to say - perspective on reality represents vis-à-vis the traditional Christian view of the world as the creation of a transcendent God, whose own reality is not dependent on the reality of the world. This transcendent notion of God deist thinkers of the eighteenth century had retained from their Christian heritage, but Hegel found it empty of

$82 \quad$ Blackburn (ed.), op. cit., 168.

83 Hegel, Elements of the Philosophy of Right, ed. A. W. Wood, tr. H.B. Nisbet (Cambridge, 1991), 23; cf. above, n.3.

${ }_{84}$ 'Historicism' refers to the belief that cultures and epochs can only be understood in terms of their own, particular historical constellations. This is sometimes taken to mean that all cultural products are relative to their place of origin and can make no claim to any absolute, trans-historical, or universal applicability, relevance or truth, to say nothing of providing access to transcendent truth. 
content. The reality he describes is, as Roger Scruton has pointed out, dramatically different from what, in Western culture, had been taken to be the case for centuries: '[T]hose who, like Russell, see only the pretentious exterior of his thinking, show themselves to be blind to the profound spiritual crisis that Hegel was striving to describe - the crisis of a civilisation that has discovered the God upon whom it depended to be also its own creation. ${ }^{85}$ In seeking to overcome that crisis, Hegel succeeded only in secularizing Christianity. Hence, it seems not too provocative or far-fetched to describe his thought as a secularization of theology. Marx, one might say in conclusion, took a further step, ironically reminiscent of Christinity's key doctrine of incarnation, by insisting that the crisis of Western civilisation could not be solved by thought alone, but could only be overcome by the transformation of the world through revolutionary activity. 